\title{
Pentingnya Materi Lingkungan \\ dalam Pembelajaran Bahasa Indonesia di Sekolah
}

oleh: Wiwi Noveria Husna. A

wiwinoveria998@gmail.com

Manusia tidak akan lepas dari masalah lingkungan. Hal tersebut sejalan dengan Nazarenko (dalam Ramadhan et al, 2019), yang menyatakan bahwa manusia akan selalu berhadapan dengan masalah lingkungan. Setiap manusia di dunia pasti mengalami masalah lingkungan seperti banjir, kebakaran hutan, polusi udara, dan lain sebagainya. Kerusakan tersebut pasti disebabkan oleh manusia, maka manusia harus mampu mengatasinya. Menurut Ramadhan et al (2019), kerusakan lingkungan dapat mengancam kehidupan manusia di masa sekarang maupun di masa yang akan datang. Kerusakan lingkungan bukan hanya berdampak bagi sumber daya alam saja, namun sumber daya manusia pun begitu, seperti masalah ekonomi yang akan terjadi nantinya.

Hal yang dapat dilakukan untuk mengatasi masalah lingkungan adalah dengan cara menanamkan kesadaran sejak dini akan pentingnya menjaga lingkungan agar lingkungan tersebut tidak mengalami kerusakan. Maka, hal tersebut tentu tidak terlepas dari pendidikan lingkungan yang diterapkan di sekolah. Menurut Ramadhan et al (2019), pendidikan lingkungan bertujuan untuk mengajak siswa untuk ikut serta dalam menjaga lingkungan. Sejalan dengan itu, menurut Sukma et al (2020), tujuan pendidikan lingkungan adalah untuk memberikan pandangan posistif kepada siswa mengenai cara menyikapi lingkungan dengan baik, serta menambah pengetahuan akan alam. Sehingga siswa memahami bagaimana cara beretika kepada lingkungan.

Pendidikan lingkungan tersebut dapat diterapkan dalam pembelajaran di sekolah terutama pembelajaran bahasa Indonesia. Hal ini sejalan dengan Ramadhan et al (2019), menyatakan bahwa guru bahasa Indonesia merupakan guru yang paling beruntung dari guru mata pelajaran lain, sebab guru bahasa Indoenesia lah yang dapat meningkatkan minat baca siswa, termasuk mengenai masalah lingkungan. Dengan demikian, kerusakan lingkungan dapat diantisipasi dari usia anak-anak. 
Pembelajaran bahasa Indonesia tidak akan terlepas dari keterampilan berbahasa, salah satunya yaitu keterampilan menulis. Menulis merupakan keterampilan yang paling penting dalam pendidikan, namun keterampilan menulis merupakan keterampilan yang sulit, dibandingkan dengan keterampilan berbahasa lainnya. Menurut Ramadhan et al (2020), keterampilan menulis bukanlah keterampilan yang diperoleh secara alami, tetapi dipelajari. Salah satu factor penyebab siswa kesulitan dalam menulis adalah siswa kurang mampu menentukan topic dalam menulis. Menurut Sukma, et al (2015), hal yang dapat dilakukan untuk melibatkan siswa dalam mencari sumber dalam menulis adalah dengan memfasilitasi siswa untuk berinteraksi dengan lingkungan, sehingga siswa secara aktif dapat berpatisipasi dalam menjaga lingkungan. Selanjutnya, menurut Sukma dan Safitri (2020), saat menulis gunakanlah bahasa yang mudah dimengerti, serta gunakanlah topik yang berhubungan dengan lingkungan tertentu.

Salah satu hal yang dapat memberikan inspirasi kepada siswa saat menulis adalah dengan memperkenalkaan siswa dengan lingkungan. Menurut Ramadhan, et al (2013), dalam menulis teks sastra penulis dapat menuangkan gagasannya secara kreatif, di mana karya tersebut disesuaikan dengan kondisi lingkungan. Hal ini memperlihatkan bahwa penulis peduli pada lingkungan di sekitarnya. Sejalan dengan itu, menurut Sukma et al (2020), dalam materi pembelajaran menulis teks naratif, siswa dapat menulisnya berdasarkan hal yang terjadi di lingkungan sekitarnya.

Adanya materi lingkungan dalam pembelajaran bahasa Indoenesia, siswa dapat mengembangkan kemampuan berpikir. Menurut Ramadhan, dan Tamsin Fitri, (2016), menyatakan bahwa adanya materi lingkungan dalam pembelajaran bahasa Indonesia, siswa akan diajak untuk berinteraksi langsung dengan lingkungan di luar kelas, sehingga kemampuan intelektual siswa akan berkembang. Sejalan dengan itu, menurut Ramadhan, dan Afnita, dan Sulendari, (2013), dengan adanya pembelajaran berbasis masalah pada bahasa Indonesia, siswa dapat menghadapi tantangan dalam kehidupan pada lingkungan yang semakin kompleks. 
Selanjutnya, materi lingkungan yang terdapat dalam pembelajaran bahasa Indonesia dapat mengembangkan daya imajinatif siswa dalam menulis. Hal tersebut sejalan dengan Ramdhan et al (2018), penggunaan pendekatan lingkungan dalam pembelajaran menulis terbukti dalam meningkatkan keterampilan menulis siswa. Menurut Mulyasa (dalam Ramadhan et al, 2018), pendekatan lingkungan yang diterapkan dalam pembelajaran bahasa Indonesia dapat melatih siswa untuk mengamati apa saja yang terjadi di lingkungan sekitarnya, baik di dalam lingkungan sekolah maupun di luar sekolah. Menulis yang terinspirasi oleh alam akan membuat siswa termotivasi untuk mengetahui segala hal tentang lingkungan alam sekitar.

Berdasarkan permasalahan yang dijabarkan di atas, penulis melakukan penelitian mengenai kaitan pembelajaran bahasa Indonesia dengan lingkungan, di mana responden dalam penelitian ini adalah mahasiswa. Penelitian ini dilakukan dengan membuat 10 pertanyaan dalam bentuk angket google form. Hasil yang didapat dari penelitian ini adalah sebagai berikut. Pernyataan pertama yaitu materi lingkungan sangat penting dalam pembelajaran bahasa Indonesia, 66,7\% menyatakan setuju, 33,3\% menyatakan sangat setuju, 0\% menyatakan kurang setuju, dan $0 \%$ menyatakan tidak setuju. Pernyataan kedua adalah sikap menjaga lingkungan selalu diterapkan selama proses pembelajaran bahasa Indonesia, 60\% menyatakan setuju, 33,3\% menyatakan sangat setuju, 6,7\% menyatakan kurang setuju, dan 0\% mentakan tidak setuju. Selanjutnya, pernyataan ketiga adalah dalam pembelajaran bahasa Indonesia, materi lingkungan merupakan topik yang menarik untuk dipelajari. $70 \%$ menyatakan setuju, $26,7 \%$ menyatakan sangat setuju, 3,3\% menyatakan kurang setuju, dan 0\% menyatakan tidak setuju

Selanjutnya, pernyataan keempat yaitu dengan adanya materi lingkungan pada pembelajaran teks, siswa dapat meningkatkan pengetahuannya tentang lingkungan, 63,3\% menyatakan setuju, 36,7\% menyatakan sangat setuju, 0\% menyatakan kurang setuju, dan $0 \%$ menyatakan tidak setuju. Pernyataan kelima adalah dalam pembelajaran bahasa Indonesia, materi lingkungan dapat mengurangi kejenuhan siswa dalam proses belajar mengajar, 66,7\% menyatakan setuju, 26,7\% menyatakan sangat setuju, 6,7\% menyatakan kurang setuju, dan $0 \%$ 
menyatakan tidak setuju. Pernyataan keenam adalah materi lingkungan dalam pembelajaran bahasa Indonesia memudahkan siswa dalam menuangkan ide dalam bentuk tulisan, sehingga siswa dapat meningkatkan keterampilan menulis $60 \%$ menyatakan sangat setuju, 46,7\% menyatakan setuju, 3,3\% menyatakan kurang setuju, dan $0 \%$ menyatakan tidak setuju. Pernyataan ketujuh adalah upaya-upaya pelestarian lingkungan dapat ditemui dalam teks-teks bacaan pembelajaran bahasa Indonesia $60 \%$ menyatakan setuju, 33,3\% menyatakan setuju, 6,7\% menyatakan kurang setuju dan $0 \%$ menyatakan tidak setuju.

Pernyataan kedelapan adalah guru mengajak siswa mengamati lingkungan masyarakat untuk membuat teks deskripsi 66,7\% menyatakan setuju, 30\% menyatakan sangat setuju, 3,3\% menyatakan kurang setuju, dan $0 \%$ menyatakan tidak setuju. Pernyataan kesembilan berbunyi, siswa ditugaskan membuat laporan obsevasi tentang penanganan limbah di lingkungan sekitar tempat tinggal, 56,7\% menyatakan setuju, 33,3\% menyatakan setuju, 10\% menyatkan kurang setuju, dan 0\% menyatakan tidak setuju. Pernyataan kesepuluh yaitu memberikan materi lingkungan dalam pembelajaran bahasa Indonesia merupakan salah satu upaya membangun kecerdasan ekologis, 66,3\% setuju, 33,7\% menyatakan sangat setuju, $0 \%$ menyatakan kurang setuju, dan $0 \%$ menyatakan tidak setuju.

Berdasarkan hasil peneltian tersebut, dapat disimpulakan bahwa materi lingkungan sangat penting diterapkan dalam pembelajaran bahasa Indonesia. Dengan adanya materi lingkungan dalam pembelajaran bahasa Indonesia, siswa dapat membengun kecerdasan ekologis. Untuk menerapkan materi lingkungan tersebut, tentu diperlukan guru yang bisa memotivasi siswa untuk cinta kepada lingkungan. Menurut Sukma et al (2020), guru merupakan orang yang paling berpengaruh dalam menanamkan pendidikan lingkungan sejak dini. Guru menjadi panutan bagi siswanya di masa depan, karena perilaku siswa dipengaruhi oleh perilaku guru. 


\section{DAFTAR PUSTAKA}

Ramadhan, S, et al. 2020."Design of learning Modules Writing Narrative Text Based on Project Based Learning (PBL) by Using Mobile Devices. “JPhCS 1471.1.

Ramadhan., Afnita, \& A Yantama, S. P., (2018). Penerapan Pembelajaran Berbasis Masalah dalam Pembelajaran Teks Puisi untuk Siswa Kelas VIII SMP Negeri 4 Sungai Penuh. Pendidikan Bahasa Indonesia, 7(4), 104-114.

Ramadhan, S., Sari \&, Hasanuddun, W.S., (2013). Majas Lokalitas dalam Kumpulan Sajak Mangkutak di Negeri Prosaliris Karya Rusli Marzuki Saria. Bahasa, Sastra, dan Pembelajaran, 1(2)

Ramadhan, S., Sukma, E., \& Indriyani, V. (2019, August). Environmental education and disaster mitigation through language learning. In IOP Conference Series: Earth and Environmental Science (Vol. 314, No. 1, p. 012054). IOP Publishing.

Ramadhan., Tamsin, A. C, \& Fitri, Y., (2016). Pengaruh Model Pembelajaran Kooperatif Tipe Think Talk Write Berbantuan Media Gambar terhadap Keterampilan Menulis Karangan Argumentasi Siswa Kelas X SMA Negeri 5 Padang. Pendidikan Bahasa Indonesia, 5(2), 548-554.

Ramadhan, S., Viodelf, , R., \& Miaz, Y. (2018, April). Increasing writing skill of narrative and motivate students class IV primary school through environment approach. In International Conferences on Educational, Social Sciences and Technology (pp. 270-275). Fakultas Ilmu Pendidikan UNP.

Sukma, E., \& Annisa Safitri. 2020. Peningkatan Hasil Belajar Siswa pada Tema 3 Menggunakan Pendekatan Saintifik di Sekolah Dasar. Jurnal Pendidikan Tambusai (Vol. 4, No. 3) 
Sukma,E., Amelia, \& Asma. 2015. Pembelajaraan Menulis Laporan Percobaan Dengan Pendekatan Saintifik di Sekolah Dasar. In Prosiding Seminar Nasional Jurusan PGSD FIP UNP Tahun 2015 (Vol. 1, No. 1).

Sukma, E., Ramadhan, S., \& Indriyani, V. (2020, March). Integration of environmental education in elementary schools. In Journal of Physics: Conference Series (Vol. 1481, No. 1, p. 012136). IOP Publishing.

Sukma, E., Suriani, A., Putera, R. F., Habibi, M., Sukirno, T. 2020. Direct Writing Activity: A Strategy in Expanding Narrative Writing Skills for Elementary School. Universal Journal Of Educational Research, 8 (10), 4374-4383. 